Meta

Journal des traducteurs

Translators' Journal

\title{
Translation and the Dialectics of Difference and Equivalence: Some Theoretical Propositions for a Redefinition of the Source-Target Text Relation
}

\section{Lieven Tack}

Volume 45, numéro 2, juin 2000

URI : https://id.erudit.org/iderudit/004320ar

DOI : https://doi.org/10.7202/004320ar

Aller au sommaire du numéro

\section{Éditeur(s)}

Les Presses de l'Université de Montréal

ISSN

0026-0452 (imprimé)

1492-1421 (numérique)

Découvrir la revue

Citer cet article

Tack, L. (2000). Translation and the Dialectics of Difference and Equivalence: Some Theoretical Propositions for a Redefinition of the Source-Target Text Relation. Meta, 45(2), 210-227. https://doi.org/10.7202/004320ar
Résumé de l'article

À quel niveau de l'analyse (descriptiviste, empirique, épistémologique) et selon quelle perspective (sociologique, communicationnelle, linguistique) faut-il situer les critères qui permettent de dégager la traduction comme un objet scientifiquement délimité ?Autrement dit, quelles sont les conditions nécessaires et suffisantes pour que se constitue l'objet " traduction ", cet objet-là seulement et pas un autre? Telle est la question générale que pose cet article, et cela en deux temps. Il s'agira d'abord de démontrer que la voie suivie par la traductologie, qui définit la traduction par son rapport d'équivalence sémantique ou fonctionnelle à un texte de départ, a pour corrollaire idéologique et institutionnel l'exclusion discursive de la théorisation de ce qui est la condition de possibilité initiale de toute traduction : la rupture et la mise à distance par lesquelles l'humain structure sa relation sociale. C'est par la critique des théories de la communication, dans lesquelles la traductologie a cherché ses assises scientifiques, qu'un fondement épistémologique de la traduction dans la structure de la relation sociale devient possible. Dans un deuxième temps, on essaiera d'argumenter que la traduction, tout en étant structurée par une dialectique sociale, n'est pas suffisamment définie par cette dialectique qui dé- passe le seul domaine de la traduction interlinguale. Celle-ci reçoit son critère de spécificité par la nature hybride des relations référentielles qu'elle établit tant avec le monde à dire qu'avec le texte de départ à reformuler.
Ce document est protégé par la loi sur le droit d'auteur. L'utilisation des services d'Érudit (y compris la reproduction) est assujettie à sa politique d'utilisation que vous pouvez consulter en ligne.

https://apropos.erudit.org/fr/usagers/politique-dutilisation/ 


\title{
Translation and the Dialectics of Difference and Equivalence: Some Theoretical Propositions for a Redefinition of the Source-target Text Relation'
}

\author{
LIEVEN TACK \\ Katholieke Universiteit Leuven, Belgium
}

\begin{abstract}
RÉSUMÉ
À quel niveau de l'analyse (descriptiviste, empirique, épistémologique) et selon quelle perspective (sociologique, communicationnelle, linguistique) faut-il situer les critères qui permettent de dégager la traduction comme un objet scientifiquement délimité? Autrement dit, quelles sont les conditions nécessaires et suffisantes pour que se constitue l'objet «traduction», cet objet-là seulement et pas un autre? Telle est la question générale que pose cet article, et cela en deux temps. Il s'agira d'abord de démontrer que la voie suivie par la traductologie, qui définit la traduction par son rapport d'équivalence sémantique ou fonctionnelle à un texte de départ, a pour corrollaire idéologique et institutionnel l'exclusion discursive de la théorisation de ce qui est la condition de possibilité initiale de toute traduction: la rupture et la mise à distance par lesquelles l'humain structure sa relation sociale. C'est par la critique des théories de la communication, dans lesquelles la traductologie a cherché ses assises scientifiques, qu'un fondement épistémologique de la traduction dans la structure de la relation sociale devient possible. Dans un deuxième temps, on essaiera d'argumenter que la traduction, tout en étant structurée par une dialectique sociale, n'est pas suffisamment définie par cette dialectique qui dépasse le seul domaine de la traduction interlinguale. Celle-ci reçoit son critère de spécificité par la nature hybride des relations référentielles qu'elle établit tant avec le monde à dire qu'avec le texte de départ à reformuler.
\end{abstract}

\section{ABSTRACT}

At which level of analysis (descriptivist, empirical, epistemological), and along which perspective (sociological, linguistical, communicative), should we locate the distinctive criteria for the definition of translation? In other words, what are the necessary and sufficient conditions which constitute the object "translation," exclusively this object and not any other object? This is the general question of this article. It will be developped in two steps. First, we shall try to demonstrate that the perspective adopted by translatology, in defining translation by its semantical and fonctional equivalence relation with a source text, is congenetically determined by the discursive exclusion of the theorisation of that which is the very condition of possibility of each translation: the disrupture and distancing by which humans structure their social relation. Consequently, it is by the critique of communication theory, where a large part of translatology has drawn its scientific foundations, that we can deliver sound arguments for the assessing of translation in the structure of social relations. A second step consists in the formulation of a working hypothesis: if translation may be caused by the social dialectics of distancing and negociation of meaning, it is not sufficiently specified by this logic. It could be hypothesized that translation finds its specificity in the hybridity of the linguistic referential relation it instaures with the mute universe to be conceptualized on the one hand, and with the source text to be reformulated on the other.

\section{MOTS-CLÉS/KEYWORDS}

epistemology of translation, anthropological foundation of translation, theory of mediation, translational specificity

Meta, XLV, 2, 2000 
Essentialism has, for a certain time now, become completely outdated in scientific writing. Who would nowadays dare to entitle a publication using the famous formula "What is $x$ "? The question reminds us of an intellectual concern in the human sciences with stable and long-lasting definitions, which ran through a large segment of European thought and which we are happy to leave far behind. At present we like to stress the heterogeneity of the discursive reality we try to convey, the relativity of our own scientific practice, the reflexive ambiguity of our relation to the object. No doubt this is a sane, salutary and profitable evolution: it stimulates new research; it helps us to look at what we seem to know from a different perspective.

However, any evolution towards a new socially established practice only succeeds by discursive and ideological elimination of that which it is not. In scientific evolution, we can, by way of example, say that what nowadays counts as scientific research is at the antipodes of the naive positivistic optimism of the turn of the century. In a way, such elimination is a discursive condition for the positive affirmation of a new mode of thinking. The oppositional dynamic between general patterns of thought not only has a socializing function, it also helps us to move on; it gives us indications of where we come from and do not want to go back to. Some of these historical oppositions are quite neutral landmarks of scientific history. But they can also turn silently into negatively connoted scientific taboos. They are no longer unsaid because scientifically erroneous, but unsayable because, for more conjunctural reasons, they are incompatible with dominant theoretical presuppositions.

Today, essentialism is one of these spectres of scientific practice, in Translation Studies as elsewhere. It is unfashionable and extremely naive to ask what translation is. For descriptivists, it is simply not done because it reminds us of the prescriptivist pretensions of our predecessors. But more hardcore theoreticians also avoid absolute questions to which no straightforward answers (i.e. justified by elements of factual proof) can be given: such issues are rhetorical, scientifically unproductive. They oversimplify the phenomenal complexity of historical reality. In a word, they are useless.

But perhaps the banishment of essentialism also had another effect. Could it be that the suspicion cast on homogeneous objects has also turned a series of fundamental epistemological questions into 'usual suspects'? Let us take a closer look at this useless question: What is translation? In other words, what are the minimally necessary and sufficient conditions for translation to exist? What is the nature of these conditions? What are the perspectives that such questions can lead to? Clearly, this is not a literal question. The goal is not to produce a dictionary definition. Two aspects of the question will be highlighted in this article.

The first issue concerns the scientific accountability of the object /translation/. The question needs to be raised, from an epistemological point of view, if translation contains its own, translational principles of explanation. If this is the case, consequently, translation justifies a "Science of Translation," i.e. a separable and independent discipline whose task it is to formulate the explanatory laws (or determining principles) of a specifiable object of study. If not, if it is impossible to locate determining principles which apply only to translation, if, in other words, the explanation of translation seems to involve laws and regularities that apply to larger domains of human social activity, then the theory of translation will result from the study of more general social and linguistic features. What consequences would the integration 
of translation into a more general science have on the very definition of translation? It will be argued that when the specificity of translation, in opposition to non-translational phenomena, is not taken for granted but critically questioned, this may in the end help to better relate translation to the ground of its theoretical causation and condition of possibility. The central point here is to argue that the condition that makes translation possible and that is constitutive of translation, is the intrinsic differentiation process of human society. Man is anthropologically compelled to create borders, distinctions and distances in gender relations, family ties, oppositional social classes, competing professional groupings, and, yes, different linguistic "communities," from village sociolects to the lingua franca. Translation is fundamentally structured by the negotiation of these differences, but not specified by them: any social interaction deals with this anthropological structure.

The second issue dealt with here is the problem of the relation between the embeddedness of translation in social structures and the other dimension fundamentally constitutive of translation: language. Clearly, translation is not only formalised by sociological laws; it is also a linguistic phenomenon, a fact of language, and it therefore raises theoretical questions that have been the concern of Linguistics. I am specifically concerned here with the problem of referentiality in translation. More precisely, translation seems to problematize the articulation between linguistic sign structures as fundamentally negative entities - what Saussure called "la valeur" -, and the referential reality, i.e. the world to be understood via a meaningful conceptualisation. Meaning results from the confrontation of formal textual structures with that part of reality (the referent) which is to be conceptualized. The translated text is meaningful in a specific way due to the diversification of the referent. Can we speak of a double referentiality in translation? We could hypothetically say that the translated text linguistically conceptualises (1) a part of reality which we try to understand adequately: it is through the confrontation of the textual features of the translated text with our personal experience and conceptual frame that a meaningful concept of reality takes concrete shape in our mind; (2) that the translated text conceptualises another (chronologically anterior) textual construct of reality, that of the source text. A reference always being a relation between two levels, it is theoretically possible for us, as scholars, to investigate primarily the referential relation of the translated text to the source text. This issue can be linked with the first one when we hypothesize that the specificity of translation lies in the hybridity of its referents.

In short, translation is a phenomenon with social grounding (without the social law of diversification and incommunicability, clearly there would be no translation, nor communication for that matter). But it is also a social phenomenon which does not possess sociologically distinctive features allowing for the constitution of /translation/ as a specific object of sociological analysis. On the level of its causation principle, translation has no power to distinguish itself from non-translation. The social demand for equivalence is a general one, not restricted to translation. On a linguistic basis however, the problem of referentiality is specific to translation.

My adressing of these issues is very largely indebted to a new epistemological approach to the human sciences still in the process of elaboration by a contemporary Franco-Belgian research group: a theoretical paradigm known as la théorie de la médiation $^{2}$ (from now on TM), whose founding father is the French anthropologist and linguist Jean Gagnepain (see Gagnepain 1982/1991). 


\section{Definition of /translation/: A Matter of Life and Death for Translation Studies}

The problem of how to define translation is probably as old as translation. It has been formulated and 'solved' in various ways, often depending on the particular needs and aims of the existing historical and socio-cultural configurations. At present, as reflection on translation is more and more institutionalized in university programs and benefits from the aura of a legitimate scientific discipline, the question of definition is correlated to the delimitation of the field of Translation Studies. It is to the extent that translation can be defined as a specific activity, requiring specific investigation methods, that Translation Studies justifies its very existence.

Any definition of translation seems to be based on the premise of an equivalence in the translational relation from Target Text to Source Text. Even when translation is related to larger communicative processes, the equivalence relation is held to be its specificity in the last resort (Chesterman 1997). In other words, what defines translation is the possibility of relating two different texts, because they can be said to have things in common: the translation stands in an equivalence relation to a pre-existing text in many "relevant aspects" of equivalent (or resembling) value in both texts. This concept, although very diversified in the various subareas of Translation Studies, basically draws on the same presupposition. Various other notions, such as "relevant similarity" (Chesterman), "interpretive resemblance" (Gutt), and even Davidson's principle of charity and conceptual schemes linking assumption of truth to translatability, all seem to take the premise of a common basis between source and target as a sufficient definition of translation. A fundamentally identitarial - ideologically not neutral - conceptualization of translational communication and human interaction in general is the sensus communis of all definitions.

Both from a historical and a disciplinary perspective, focus on equivalence to define translation is probably the most common feature of translatology. The abundance of theorizations about equivalence, in fact the result of translational activity, is all the more striking when seen in opposition to the quasi-absence of attempts to conceptualise the sociological grounds of the lingual differentiation processes ${ }^{3}$ which drive people to translate in the first place. It is surprising to see that Translation Studies searches no definitional pertinence in a theory of the socio-cultural differentiation of any human activity. It can be argued, with reference to TM, that if translation is apparently about the establishing of an equivalence relation, its prime scientific accountability lies in the implicit sociological differentiation process governing the human construction of society.

\section{Non-epistemological discussions about equivalence}

Before we go on with this, let us first take a closer look at how problems with equivalence have been dealt with in certain areas of translatology. Indeed, if scholars agree to take equivalence as defining translation in the last resort, there is no consensus on what the equivalence actually consists of. It has been accurately pointed out that the problem of the object of equivalence has governed the whole discussion, to the point that the question of the existence of equivalence has been taken for granted (Pym 1992: 39). In very general terms, it seems that two major concepts of equivalence 
have dominated the scene of Translation Studies in the 1970's and 1980's. Both can be read as a response to Quine's assertions that meaning in language is always contructed, never identical to itself since there is no "fact of the matter" somewhere out there, no reality that is intellectually accessible to us beyond linguistic signification. The de-positivization of linguistic signification, established since Saussure and picked up by Hjelmslev, is a radical problem for stable meanings supposed to be equivalent. Reasonable doubt exists about the validity of the equivalence concept in its absolute sense. ${ }^{4}$

A first series of reactions to Quine's “indeterminacy thesis" consists of assessing the possibility of translation on a weakened version of the ideal equivalence. In reality, these "essentialistic" reactions, as convincingly shown by Hjorst 1990, could be the result of a fundamental misinterpretation of the sceptical interrogation (of equivalence as a basis for absolute translatability). Indeed, it would be inadequate to read Quine's scepticism about the possibility of absolute equivalence as a substantial statement for impossibility of translation. Quine's essentialistic interpretations deal with various efforts to diversify the equivalence concept in order to make it more operative. To take but one famous example, Davidson's proposal of a "principle of charity" involved an assumption of truth shared by any subject no matter which language or culture he belongs to. What explains the possibility of translation is thus a universal(ist) assumption by which each individual accords truthfulness to the interlocutor's statements. The eventuality of divergence of their interpretation from the intention of the original remains possible, but is of secondary importance. It needs to be stressed that this apparently purely "logical" hypothesis from the philosophy of language has far reaching implications on an ideological or sociopolitical level.

The second interpretation of Quine's thesis integrates in its answers Quine's interrogation of the idea of absolute translatability. Non-essentialistic definitions of translation theorize the other element which, besides the source text, strongly determines translation: the expectations, norms, conventions of the target culture which the translator tries to meet, change or reinforce. ${ }^{5}$ According to this functionalist approach to translation, equivalence must be related to its historical implementation. The substantial definition of translation by an a-historical exclusive ideal of equivalence is dismissed as transcendental; instead, the functionalist approach grounds its scientificity on an empirico-historical reasearch-basis. The concept of equivalence still holds as essential to the translation process, precisely in the fact that it is, like the norms and conventions of text production, submitted to socio-historical change. Equivalence is no textbook notion, it has cultural existence, manifested in relevant textual and extra-textual features, legitimized in often merely silent agreements which make translations acceptable for a given community or public. For a text to be considered a translation, it now suffices that it be considered "equivalent enough" (Hjorst 1990) to a pre-existing source text by a given target culture. The emphasis changes; the presupposition of equivalence as sufficient definition of translation in the last resort remains. Why is this so?

\section{Equivalence: an institutional problem}

My hypothesis for the surprisingly pervasive insistence on equivalence as the fundamental dimension of translation is that research on the definition of transla- 
tion is essentially biased by ideological and institutional preoccupations. Dependent on the answer to the question how translation can or cannot be seen as a process presenting different (= specifiable) features from other communication processes, translation will either require Translation Studies as a discipline or will legitimately be studied by an adjacent discipline (communication theory, sociology, sociolinguistics). The latter possibility, according to Kirsten Malmkjaer, "reduces the study of translations and translating to a sub-area of the discipline which has produced the chosen theory" (Malmkjaer 1993, my emphasis). But why should the integration into another discipline necessarily imply the Dark Ages of translation studies? Rather than a regrettable "reduction to a sub-area," the study of translation by a different scientific discipline could end up being a very productive and illuminating approach to translational phenomena. One may indeed wonder what exactly we want to achieve: are we looking for a better understanding of translational phenomena, or is our first object to save translation from the frightening imperialism of other disciplines? The first goal is only concerned with finding out what theory offers the most comprehensive insights, independently of whatever discipline it is formulated within; the second would have scientific investigation be dependent on the need for a specifiable subject. Thus, scientific discourse may quite rapidly turn into ideological discourse, as Malmkjaer almost overtly illustrates:

[I]t is through theorising about translation that the impossibility of establishing any theory of translation whatsoever has been postulated most forcefully. What we need, it seems to me, is an argument that can underpin our theoretical efforts (Malmkjaer 1993: 135).

Two remarks can be made here. First, it seems at least useful, rather than fighting desperately against self-destructive theorising, to investigate translation studies on this particular delegitimization of its own object: if it is so difficult to establish a specific theory, it may be more reasonable to address translation from a different viewpoint. Second, this needn't be a suicidal operation: by giving up the idea of an exclusive theory of translation, a true theoretical account of translation can perhaps successfully emerge. If it happens to be problematic to specify translation from non translation, we can at least hypothesize that theory of translation is bound to consider in the first place a series of determining principles of society and language in general.

This is all the more so since need for a fundamentally open attitude to other scientific approaches seems to result from the nature of the object /translation/ itself. It can respond to the demand for interdisciplinarity so often formulated, on condition that interdisciplinarity be understood as an attitude which refuses to draw new disciplinary frontiers (in combining two disciplines, one in fact simply multiplies the borders by creating a new research field; the recent emergence of "Interart Studies" is a good example of this paradox). True interdisciplinarity consists in the scientific exploration of a no man's land, where different questions about an object can be confronted with each other, without necessarily being complementary (i.e. not very far from consensual, and thus from the end of science). ${ }^{6}$

\section{First conclusion and new challenges}

The establishment of a specific criterion adequate to the definition of translation seems thus almost exclusively linked with the analysis of the (essential or historical) 
relation of a translation to its source. In other words, it is the final result of translation which is addressed to delimit the object of investigation. So far, to my knowledge, few definitions of translation theoretically take into account the two poles between which any translation can be said to balance: (1) some (culture-bound) concept of equivalence as the "result" to achieve, and (2) the unerasable difference in languages, cultures, social classes, which puts a serious caution on efficient human communication, and which is always the very cause of translation in the first place. The complex relation between these poles is clearly not of a linear or chronological nature. They imply each other, they stand as (socio)logical moments to each other in a dialectical relation.

Equivalence is definitely a relevant and fundamental aspect of translation, but not the only one. Translation cannot be theorized if the difference pole is not thought of as always co-present with equivalence. Equivalence cannot explain translation; it does not account for the anthropological necessity to translate. ${ }^{7}$ If science claims to formulate general laws about a certain phenomenon, these laws can be conceptualised as structural principals both sufficient and necessary for the phenomenon to take place. For example, in general terms, it is the aim of Linguistics to formulate the determining principles which operate as sufficient conditions for semantico-phonetic elocution to take place. The challenge for Translation Studies would be to address these issues in the case of translation. One would have to establish structural principles that can be isolated as the specific conditions of possibility for translation. Only the answer to this issue can legitimately formalise translation as an independent object of study. What are the conditions that function as causation principles of translation? The human need for efficient communication? The selffulfilling prophecy of intercultural relations as an ethically rewarding answer to devastating warfare? Or is there an overall compelling necessity at stake?

\section{Innovative Aspects of the théorie de la médiation $(\mathrm{TM})^{8}$}

\section{What is mediation?}

The term 'médiation' refers to the hypothesis that nothing in human behaviour is immediate, that humans, in contrast to animals, live up the relation to the world by mediation of a mental, structural process of abstraction from naturally determined behaviour such as sensitive perception, physical gesture, natural drives, etc. This general hypothesis from French structuralism does not remain speculative in TM but relies on clinical observation of mental pathologies. The inspiration by a Popperian methodology which uses clinical analysis as an empirical falsification basis ${ }^{9}$ for theoretical hypotheses is in fact one of the most important heuristic innovations of TM. It results in a coherent model of four mental structural faculties: four principles of one general human dialectical rationality. The fourfold model is deduced from an "analytico-pathological" procedure: the systematic observation of the selectivity of the mental pathologies (aphasia, apraxis, psychosis, nevrosis) allows for the theorisation of distinctive models along the breaklines of each pathology.

Example. In the application of the analytico-pathological hypothesis in clinical observation, it seems possible to specify different models of rationality. An aphasiac, disabled in his capacity of grammatical generation of meaning, is on the other hand still perfectly able to communicate socially (they will correctly analyse their discursive 
position in relation to the other, for instance with respect of the formal/colloquial register and tone of the conversation). The grammatical disease has of course repercussions on his conversation, and thus creates a problem for communication, but is not a disability of communication (as is autism for example). It then seems justified to hypothesize that language always involves, on different theoretical levels, a formal grammatical dimension, and a communicative, an interactive dimension. The analytico-pathological principle offers scientific arguments to deconstruct what presents itself as phenomenally complex.

This process of deconstruction ${ }^{10}$ of human reason is summarised by JeanClaude Schotte as follows:

[La théorie de la médiation] thématise quatre ordres rationnels finis, en conjecturant que cette simplification "quartésienne" rend possible la spécification de faits nécessaires, indépendants d'autres faits ayant leur propre nécessité. Elle diffracte la négativité, c'est-à-dire la raison humaine, en quatre facultés différentes et indépendantes: la faculté d'analyser structuralement l'expérience perceptuelle, soit la grammaticalité (l'homme parle, il rend le monde intelligible); la faculté d'analyser structuralement les mouvements, soit la technique (l'homme utilise des outils, il artificialise ses opérations); la faculté d'analyser structuralement la vie de l'espèce, soit l'ethnique (l'homme vit contractuellement, il historise le devenir animal); la faculté d'analyser structuralement les passions, soit l'éthique (l'homme se contraint moralement, il rationne ses plaisirs). (Schotte 1997: 157-158).

On each of these levels, the relation to reality is hypothesized as mediated via a dialectical process. ${ }^{11}$ This relation is believed to be four times specifiable on a grammatical, technical, ethnical and ethical mode; in complex phenomena, such as language, it should be possible to distinguish between different types of rationality. In everyday life, these different levels always intersect, but they remain nevertheless separate, since they can be selectively the object of pathological breakdown.

\section{What is structure?}

The structural faculty, first theoretically developed by Saussure as distinctive for language, and thus for a human science of linguistics, is extended by TM to other domains where humans invest rationality: society, ethics (drawing on the structural subconscious of Freud-Lacan), and technique. A coherent conceptual apparatus has been developed by theoretical analogy with the formal structuralist explanation of language.

The structural basis of the four essentially human faculties implies that what language, technique, social interaction and emotions have in commun is their radically negative foundation. This means that nothing has a substantial existence prior to the structural analysis. It takes a radically Hjelmslevian concept of structure to reject substantialism. Structure, he writes, is:

une totalité [qui] ne se compose pas d'objets mais de dépendances et $[\ldots]$ ce n'est pas sa substance mais bien les rapports internes et externes qui ont une existence scientifique. [...] Postuler des objets comme quelque chose de différent que des termes de rapport, c'est introduire un axiome superflu et une hypothèse métaphysique dont la linguistique ferait mieux de se débarrasser. (Hjelmslev 1968-71: 36-37, cited in Schotte 1997: 44) 
The structural concept implies a radical de-positivization of the relation to reality which the structure analyzes. TM hypothesizes this radical de-positivization on the four levels of rationality (the linguistic Sign; the technical Craft; the ethnical Person; the ethico-normative Desire). The structuralist negativity (of semes on one level, of social parts and figures adopted by our personality on another level, etc.), explains the fact that no meaningful word fully coincides with a stabilized dictionary meaning, that no role socially adopted is identical to the whole of a personality.

\section{The need for a deconstruction of language $e^{12}$}

The main interest for translation scholars to be drawn from this approach concerns the "deconstruction" of the object 'language' into two different principles of determination: a "glosso-logical" and a "socio-logical" principle.

Glossology concerns the science of the Sign: its object is the processes (structural and referential) at stake in every language signifying activity, in language for deaf people just as in ordinary language. Basically, it is concerned with our "grammatical capacity": our ability to make formal, grammatically (= logically, not in the sense of normative grammar) correct statements. A series of theorizable laws govern this formal principle, quite independently of the historical language they are made in. Through a fundamentally negative framework of Signifier and Signified, humans analyze their perception of the world before re-adapting, re-investing this principle of negativity in relation to a reference. The relation between the structure of language and reference is always an improper one, it is never completely adequate. This fundamental inadequacy creates the possibility of polysemy, synonymy and paraphrase. The glossological, dialectical functioning is what Gagnepain calls "le plan du langage." Its theory formulates the structural principles which are alone necessary and sufficient for the construction of specifically linguistic facts: phonemes, semes, concepts, phonetics. These facts alone, independantly of what communicative purpose they may serve, specify the establishment of a language mediated, referential conceptualization of the world.

The specificity of the grammatical principle implies that it is scientifically separable from its its sociological, historical diversification and implementation in a given tongue (or rather in an idiolect, since the idea of homogeneity of languages is illusory). The general grammatical capacity to structure our intellection of the world is historically manifested in any particular tongue. The historicization of language implies a socially differenciating analysis of the general linguistic functions through an enormous oppositional variety of discursive registers, of different vocabularies, pronunciations, ways of telling stories etc. In short, "la langue est une question d'appropriation et de communication du signe" (Gagnepain 1994: 143).

This means that any tongue is based on a social logic which invests general linguistic structures in social interaction, historical processes and structuration of society. TM defines the concept of "la langue" (e.g. French, English, Swahili, any historical tongue) as the human ability to successfully inscribe in a socially and historically established legal usage, to conform personal speech ability to social conventionality. La langue implies a sociological analytical faculty to analyze correctly the class distinctions, power relations, dialectical particularizations etc. by which the specific discursive situation (business meeting, intimate conversation, official speech, etc.) is characterized. 
This social analytical faculty is not specific to sociolinguistic behaviour. Indeed, TM explains the infinite plasticity of humans' "personality" by their ability to adequately analyze their position to the other along more or less individual and collective differentiation criteria. On a social level, the relation of humans to society is characterized by a dialectic between an empty, structural principle ("la personne," which has no identity but is oppositional), and the investment of this "non-being" in a hic et nunc situation. This negativity, this no one-to-one correspondence between the present me and the empty structural relations of "la personne," allows for constant social singularization, differentiation, even if this needs to be re-adapted to common conventions. Structural abstraction generates divisions and hierarchies in society, makes historical recapitulations of natural becoming possible.

This general principle accounts, with regard to discursive behaviour, for the theoretical possibility of sociolinguistic differentiation, from personal language use to the macrohistorical formation of human tongues. The dialectical hypothesis serves to explain the fact that no tongue is identifiable with its fixation in dictionaries or normative grammars. Just as there is no one-to-one correlation between reference and concept, a certain variability and flexibility is indeed socially institutionalized in the way each social subject uses his tongue. An abstract negative analysis creates within one tongue a space for social divergence of idioms and dialects. It is thus an illusion to speak of French or English as one unified language, or to understand language as a principle of harmony and communication:

En ce qui concerne l'acception [i.e. "la variété (of meaning) admissible pour être compris dans une communauté"] il ne s'agit plus de locution mais d'interlocution. Il s'agit de savoir jusqu'où la différence que nous ne cessons d'instaurer peut rester recevable pour que l'autre l'accepte aussi. Bref, la dialectique à laquelle la langue participe, c'est exclusivement la dialectique ethnico-politique de la personne. Il n'y a pas de doute que cette tendance à la divergence et à la singularité — à l'idiome ou à l'idiomatisation en quelque sorte, c'est-à-dire au particularisme de langue - est absolument constante et constitue la base de la dialectique. Il est dès lors faux de dire que le langage a pour fonction de communiquer, car précisément nous ne cessons, [...] de nous l'approprier, c'est-à-dire de l'idiomatiser [...] pour être ensuite contraints précisément de le partager. [...] Le partage n'est au fond que l'autre phase dialectique [...], la phase d'investissement par laquelle on corrige les divergences que l'on a soi-même instituées. (Gagnepain, 1994: 148)

A particular tongue can therefore not be the object of a specific science, since it does not contain its own principle of determination. Grammatical regularities can be explained by more general linguistic functions operative in any tongue; the discursive registers, sociolectical varieties and the like depend on larger structuration principles and differenciation processes of society. This results from the fact that sociological exchange procedures, involving power relations, are present in any verbalization, but are not specific nor limited to verbal exchange situations.

\section{Pluriperspectivity is not the same as an integrated approach}

To explain this fundamental principle about the specificity of determinisms for the scientific construction of phenomena that are complex and diffuse in reality, Schotte draws a simple parallel with physics: 
[L] es sociologues auraient tort d'évacuer trop facilement la linguistique. Qu'un locuteur participe à la vie sociale pour échanger comme tout le monde des mots ou autre chose, qu'il se transforme donc en interlocuteur, n'implique pas qu'il arrête d'être un locuteur. Après tout, rien n'empêche un objet soumis aux lois de la gravitation d'être également soumis à des lois électromagnétiques. On ne prétend pas pour autant que la gravitation soit une illusion. (Schotte 1997: 52)

The same can be said about translation: there is no scientifically legitimate monoperspectival view which can explain translation. But this does not mean that one perspective invalidates the other. Translation theory is in need of an articulation of a kind of multiperspectivity which does justice to the scientific specificity of each approach. The goal is not to integrate all disciplines in a complementary paradigm, but to specify the different analytical views of the dimensions which constitute translation as one total phenomenon.

To go back to the case of language, this implies that fundamental linguistics (sometimes identified by sociologists with anhistorical idealism) and sociolinguistic theory of language are not mutually exclusive. A scientific procedure of analysis of pathologies forces us to distinguish two anthropological principles. By the rationale of deconstruction of faculties which together formalise the phenomenal totality of language, TM presents theoretical arguments to retain the distinction langue/parole which the scientific impasse of structuralism (its incapacity to reconcile the invariance of the structure with a concept of history other than a succession of synchronies) seemed to have shown to be untenable (again, in Bourdieu's sociolinguistic (sociocentristic?) view of language ${ }^{13}$ ). Regarding sociolinguistics, TM pleads for a new articulation of systemicity and historical linguistical usage, by dissociating the specifically linguistic grammatico-referential function from the discursive social activity, which happens to be verbal, but which is explained by larger sociological principles.

\section{Consequences for Translation Theory}

The general hypothesis of TM regarding translation is based on the epistemological premise that translation does not exist as an object of science. It is too complex, and in order to be explained, it has to be split up in different levels: the structuralist organisation of language and the social divergence which constructs interrelations through language, gender, profession etc. Only on each of these levels, each of which is specific enough to be an object of science, can translation be open to theoretical explanation. It is basically insufficient, in order to construct its theorization, to study the material manifestations of translation. ${ }^{14}$ Since cultural phenomena do not exist as directly accessible positive entities, their scientific accountability relies on their articulation with the abstract structures which formalise them. The specificity of these structures alone allows for the theoretically legitimate delimitation of disciplinary boundaries. TM relates human facts to their determining principles. This implies a scepticism regarding scientific methods which would have explanation depend on specific material conditions of recognition of a distinct phenomenon (e.g. translation). Such a position, according to TM, risks reducing science to a mere cumulative addition of approaches of the phenomenon of translation, which are only differentiated by the conditions of observation. ${ }^{15}$ It is by dissecting translation, by relating its "linguistic" and its "socio-linguistical" aspects to different principles of explanation, that a new view of the translational process becomes possible. 


\section{Translation is grounded on a social process}

In the view of TM, the theoretical causation principle is of a sociological order, and is not specific to translation. Translation is possible because of a compelling principle in human society: the existential necessity to set up differenciations, distances and borderlines at all social levels: sociocultural, sociolinguistic, professional, artistic, etc. Manifestations of this principle are infinite: class oppositions, ethnical particularities, dialectical idiosyncrasies, artistic style differenciation (in poetry, architecture, music...), sociocultural habits, clothing, etc. This social diversification process, apparently a threat of foreclosure to communication, of misunderstanding, in fact paradoxically makes communication, and translation, possible. It is the very raison d'être of translation. Therefore, to define communication, as Gutt (1990) argues, by a principle of relevance, to define human interaction by the goal of maximum efficiency, to find the basis for translation in the shared ground of a principle of charity striving for minimization of disagreement (Davidson), creates an optical illusion which melts us all together in communication exchanges. The prime interest of theoreticians in the apparent goal of communication to reach optimal understanding seems to create the side-effect of a theoretical and, to a certain extent, ideological bypass of the intrinsic process of appropriation and particularization of speech (amongst other things) in communicative interaction. Just as the technical breakdown of a computer is an intrinsic feature of its technicity, misunderstanding, as well as overand underinterpretation, are fundamental aspects of communication, just as fundamental as the various efforts to minimize its disruptive effects. Verbal interaction is structured by an intersubjective struggle to have the floor and to keep it, and thus to dispossess others of access to speech. The theoretical fixation on the efficiency and transparency of communication, based on an idealized version of absolute exchange, operates as an "epistemological obstacle" to attempts to put the social logic of speech appropriation at the core of communication and translation theory.

TM offers a serious alternative to this tendancy. It tries to define translation from a perspective which is not biased by the exclusive priority of communicative concerns. The logic which constitutes translation is a dialectical articulation between the differenciation moment of social and discursive positions with constant efforts to deal with these particularizations in communicative situations. Language participates in this dialectical articulation and can therefore not be defined by the efficiency of communication. It is impossible to take the existence of language as ontological social evidence, to see language as a social space generating its own principle of origination, be it communication, or relevance, or efficiency. Dealing with translation inevitably means tackling the aporetical law of all communication: the more we actually (= efficiently) exchange, the less need there is to communicate, or to translate. ${ }^{16}$ In translation, the differential moment may be apparently hidden by the problematic discursive stance of translators who need to make themselves invisible, ${ }^{17}$ but it is never completely absent (any translation is a decision process and leaves its marks on the text), and can also be exhibited, be it involuntarily (discussion in Hermans 1999: 144-146). It seems theoretically useful, in defining translation, to move the main focus away from equivalence and direct it to the study of the dialectical articulation of equivalence to the differential moment on which translation is founded. This research has recently been the object of a book-length publication by 
Jean Peeters where he applies a sociolinguistic theorization of TM to translation and to the theoretical construction of the socio-professional status of the translator (Peeters 1999).

\section{The impossibility of a social specificity of translation}

The causation of translation is, however, not specific to translation only: the movement of differenciation, of appropriation of language and of sharing this appropriation with others is at stake in every daily conversation. As interlocutors, we are forced to overcome these differences by a process of 'translation' of what someone said into our own understanding of it. This dialectical functioning of difference and its overcoming in society is to be scientifically investigated in translation studies. Gagnepain thus pleads for a theorization of translation "qui rapporte le phénomène de la traduction à ce qui en pose la question, et qui est à la base de la moindre de nos conversations," that is to say the appropriation of language and hence its diversification. $\mathrm{He}$ furthermore warns against the ideological tendency to relate translation to communication processes and harmonization, to the dream of contact and fusion between cultures, which is a serious obstacle for a true understanding of translation:

Parce que tout contribue à rechercher la fusion, on ne peut pas résoudre le problème de la traduction, car on nie ce qui le provoque, à savoir la diversification. (Gagnepain 1994: 154)

In Gagnepain's view there is no fundamental difference between linguistic exchange taking place in every day conversation and interlingual translation.

Le problème de la dialectique du singulier et de l'universel, c'est-à-dire de la traduction, se pose autant dans le cas spectaculaire du français et de l'allemand, [...] que dans celui de la moindre de nos conversations. Ce qui fait défaut ici, c'est une théorie correcte de la traduction. C'est parce qu'on part de l'idée fausse que les langues existent. La langue devient une instance. Or, les instances [...] ne sont toujours que le produit de nos déchirures, si j'ose dire. La langue n'existe pas, il n'existe que des ensembles plus ou moins importants de divergences et de convergences. J'ai parlé de la nécessité de l'ennemi pour fabriquer du social. Il en va de même des langues. Ce qui fait les langues mutuellement étrangères, ce sont au fond les divergences non surmontées. Mais elles sont toujours surmontables quand même, par un effort de traduction, qui n'est jamais que l'exploitation d'une nécessité qui se trouve déjà dans la moindre de nos conversations. [...] Personne ne dit exactement ce que dit l'autre. Même lorsque les mêmes mots sont dits, aucun des interlocuteurs ne les prend exactement comme les prend l'autre.

Because a particular tongue cannot form an independent object of scientific investigation, interlingual translation cannot be specifiable from intra-lingual translation. Again, none of these remarks are exactly new or revolutionary; from completely different backgrounds, similar observations are made in Pym 1992 (especially the chapter on Texts Belong, pp. 101-125, of which the last paragraphs (on embeddedness and belonging) seem to elaborate similar observations on the social functioning of tongues). The innovation of TM lies in the articulation of known insights to a general anthropological theory.

Going back to the problem of equivalence, we now perceive more clearly the raison d'être of equivalence as an important feature of translation. Equivalence is to 
be socially negotiated in a dialectical response to the distancing and appropriation of speech by any social subject. Because we constantly enact differenciations in our behaviour, because as interlocutors we appropriate language, we are forced in every conversation to relate that what is socially exchanged, within the variational degrees agreed upon by a community, to what is logically being said. This basic procedure takes place in the same way, though at a higher degree of complexity, in translational processes. Equivalence, participation in the differences and borderlines installed by communication, is a necessary phase in the human interaction process. But equivalence is not a sufficient definition of translation: it is the difference dialectically set up by the translative act which is at the core of every communicative situation.

In short: translation is not an object which contains in itself, in some translational ontology, its determining principles. Its overall causation principle, the dialectics between an analytical differenciative moment and the communal negotiation of these differences, is clearly a general feature of social interaction. The presumption of equivalence, which, according to Anthony Pym, ensues from the practice of translation and translation only, can, following TM hypotheses, also be seen as correlated to a more general social demand. Any social, economical or political interaction requires the dialectical readjustment of our particular behaviour to collective norms and identitarial regulation procedures. The communautary movement of conformity of otherness to collective habits, of reduction of the particularity which constitutes humans as persons is operative on the microlevel of all discursive utterances, of vestimentarial habits, traffic rules, and on the macrolevel of interlingual translation.

Does this entail that theory of translation is condemned to merge with sociolinguistics? Is any specificity at all to be denied to translation? From the viewpoint of its social causation principle, yes. The demand for equivalence is not a necessary and sufficient condition of a specific social object /translation/.

The question now is: is translation theory also an inclusive aspect of linguistics? Is translation an indistinct linguistic function? Or can we circumscribe in translation a linguistic problem of an exclusively translational nature? How does the translated text function as a linguistic conceptualization of a pretext?

\section{Further Consequences of TM: The Question of Referentiality in Translation}

According to my hypothesis, the social causation principle cannot explain everything about translation. It seems that translation can be related to at least two general determining principles: the sociological dialectics between ethnic differenciation and political communitization which characterizes human sociability on the one hand; the linguistic dialectics between sign structural relations and a meaningful referential conceptualization which characterises human comprehensibility of the world on the other.

It is not excluded that via the interference of the glossological and sociological level, the translational process presents itself as specific to non-translational discourse. This personal working hypothesis will be developed here.

The theoretical model first allows us to say that in translation a glossological process is at stake: as a text, it is made and understood through a rhetorical "adaptation" of an abstract signifying process to a referential world of experience. In this 
respect, it functions just as any other linguistic utterance. The specificity of translation seems to be that it refers not only to a referential world of experience but also relates to a pre-existing text, in itself an already formalized dialectical relation of structurality to a referential meaning. The translative relation to the source text is thus always double-layered.

First, there is a sociologically institutionalized dimension which explains translation via a dialectics of negotiated equivalence and difference. This level concerns all the social negotiations translation consists of: negotiation of meaning, of socio-professional responsibilities, of ideological motives, etc.

Second, it is possible to circumscribe a linguistic, textual problem regarding referentiality in translation. If, on the one hand, the social principle relevant for the whole of all translative processes explains the possibility of a communicative equivalence on the basis of a differential moment, on the other hand the linguistic or glossological principle explains the possibility of conceptualizing adequately that part of reality as expressed by the source text. The criteria for the readjustment of the distinctive sociological and linguistic abstract structural faculties to the conjunctural (communicative or referential) situation are clearly different: the first one adapts the negative social differentiation faculty to a discursive register, a conventionalized vocabulary, a general regime of sociocultural relevance for translated texts. The second criterion concerns, on a purely linguistic level, the investment of negatively structured, empty semes and syntactical constraints with a given meaning and propositional sense.

On the linguistic level, the relation of the translated text to the source text is analogous to the general negative relation of the linguistic sign to designated reality. Just as language is no nomenclature, no mirror reflection of the reality it talks about, the referential relation in translation is not mimetic. It is my hypothesis that there are sociological and linguistic reasons for the fact that no translation is a copy, or a calque of the original, even if certain historical translation practices have tended towards "literalist" versions of the source text, sometimes for the sake of aesthetic ethics.

This has consequences for the relation of the translated text to the source text. One thing is sure: the source text cannot be seen as something immediately given to the translator's mind: it is always 'constructed,' it is only apprehended, read and understood via a process of mediation. Translation is not a mechanical process of decoding the message of the source text and then re-coding it in equivalent terms. If there are social reasons for the misunderstanding and misreadings inscribed in any communicative and translative situation, there also exist linguistic reasons for the fundamental inadequacy of the textual structures to the referentialized reality (in the case of translation, the source text). The textual status of the source text is by no means a fixed entity that is positively accessible, both on the sociological and the logicolinguistic levels. It is the hypothesis of TM that the socially negotiated meaning on which both interlocutors have reached an agreement is structured by sociological processes not restricted to the area of language behaviour. On the contrary, the very fact that abstract and negative textual and grammatical structures can be invested with referential function and conceptualize a mute universe is of a strictly linguistic nature: the necessary and sufficient reasons for the emergence of the referential function are a specific function of the human faculty language and can be distinguished from social laws of communication and other types of intersubjective interaction. 
This general hypothesis of the hybridity of the referential function in translation needs refinement, but time and space lack here to develop it thoroughly. More precisely, on both the sociological and linguistic levels, the general idea of a linear directionality from source text to target text is in need of revision and correction. It could be hypothesized that the causation of translation by a social dialectics of difference and equivalence entails that translating is not, in the first place, about transgressing already existing frontiers, but that translation sets up a new division in the textual and ideological unified realm of the source text. Similarly, on the linguistic level, the relation of the translated text to the source text is not linear, but rather dialectical. The source text, as a socially meaningful construct circulating in the intersubjective flow and appropriation of information, is historically anterior to the translation. However, as a referent, it has a status of virtuality to which no direct access is possible. It follows that as textual artefact to which the translation refers, as part of the referential function which determines the conceptualization of the translation, it can never pre-exist the translation. Quine has taught us that analogically to any signifying activity, which in its structural nature never refers to a positively given reality, which is never a sign of something else pre-existing to it, in other words which is not the mere expression of a "content" exterior to the sign, translation is not translation 'of' a source text, but very much translation 'to' the source text, that it is not just reformulation of a pre-existing text, but that the source text is projected through translation, and only exists for the reader of the translation through this projection, as a referentiality constructed by the translation. Analogically to the way the linguistic signification process is an analysis of reality rather than a mirror-reflection of it, translation can be said to be an analysis of a source text. In its analysis, translation constructs the source text. The precedence of the source text is only true in terms of strict chronology. For the social communication constitutive of the translative act, there is no source but socially negotiated, politically directed and transformed; for the conceptual function constitutive of translation, there is no source but referentially constructed. The source text is always situated at both sides of the translation, which at the same time - and this is essential - analyzes it and projects it, realizes it through translation. The source text is both pre-text for the translation (without it obviously the translation would not exist) and its referential aftermath.

My reflection has perhaps raised more issues than solutions to concrete problems. Without any doubt, questions remain abundant on several levels. What to do with the non-translative linguistic and social functions which help create a meaningful conceptualization of translation? Clearly, translators' language skills, their perceptual categories, personal experience, sense of collective responsibility are all factors which operate in the referential function, just as in a non-translated text. The modalities of the concrete interaction of all these elements in the specifically translative functions are a very complex matter. The aim of this article was not to resolve them once and for all, but to indicate that translation demands an interactive theoretical framework able to account for its dialectical social and linguistic nature.

\section{NOTES}

1. Previous versions of this article have received very constructive critiques from Yves Gambier and Anthony Pym, both professors. I can only hope that their disagreement with part of what is said here does not prevent them from accepting my most sincere gratitude. 
2. Developed by Jean Gagnepain (1982/1991) at the University of Rennes II (France).

3. Language differentiation is but one area where the essentially human tendency to ethnic diversification manifests itself: think of architecture, agriculture, clothing, eating, social rituals, etc. There is no cultural fact which cannot be ethnically particularized. The term "ethnic" refers to a theoretical, negative law of differentiation; it is not "located" in any positivised hypostasis of cultural identity, historical or racial roots etc.

4. For an elaborate discussion of Quine's translation theory, see Laugier 1996.

5. This approach is comprehensively presented in Toury 1995, one of the "founding fathers" of Descriptive Translation Studies. Toury speaks of functional-relational equivalence, and relates the analysis of equivalence to the study of sociocultural and historically operative norms governing translation. The consequence of this: "What this approach entails is a clear wish to retain the notion of equivalence, which various contemporary approaches $[\ldots]$ have tried to do without, while introducing one essential change into it: from an ahistorical, largely prescriptive concept to a historical one." (Toury 1995: 61).

6. This idea is picked up in Lévy-Leblond (1996: 136). The author pleads for an "extradisciplinarity" rather than an inter- or a transdisciplinarity, in order to allow for fundamentally critical discussions and to avoid integrative models.

7. To speak of necessity is suspicious; it may recall Hegelian spiritual and political ideals in which we don't want to get involved. Yves Gambier has proposed replacing this notion with "social needs and demands" to which translation responds. I prefer to keep the original notion, with the precision that in terms of TM it is very close to Heidegger's existentials: structural, not intentionally motivated compelling processes which structure humans' linguistic, social, technical etc. relation to the other and to the world.

8. The full theoretical development can be found in Gagnepain (1982/1991). See also Gagnepain (1994) and Schotte (1997).

9. For a lucid and comprehensive introductory presentation of the advantages (and problems) of this clinical approach, see Jean-Claude Schotte (1997a).

10. As this is a central notion of the model, it is useful to stress that it has no poststructuralist connotations; what is understood here is 'dissection' of a complex human phenomenon, language in all its manifestations. A phenomenon in which language is involved, e.g. communication, cannot be defined as specific to language, and thus needs to be explained by extra-linguistic principles (in this case sociological laws).

11. A very important consequence of this is that, in the humanities, every object of study is not just something given to analyze, but is in itself already the place of analysis (pas seulement objet, mais toujours lieu d'une analyse). We are, in the humanities, always dealing with a principle of 'incorporized formalization.'

12. To make things even more complicated, TM reserves the term 'langue' for what Saussure called la parole; and uses 'langage' for what he called la langue.

13. Bourdieu says indeed: "C'est cette distinction primordiale entre la langue et sa réalisation dans la parole, c'est-à-dire dans la pratique et dans l'histoire, qui est à la racine de l'incapacité du structuralisme à penser la relation entre ces deux entités autrement que comme un rapport entre le modèle et son exécution, l'essence et l'existence. En mettant en question cette posture, j'ai essayé de surmonter les insuffisances d'une opposition entre matérialisme et culturalisme." (Bourdieu 1990: 117). His analysis presents itself more as a questioning of idealistic logocentrism than as a constructive attempt at a rearticulation of sociolinguistic procedures with structural functioning of language.

14. The scientific position of explaining human facts by the anthropological mental "faculties" which determine them rather than by cumulative descriptivism of phenomenal manifestations, is at the antipodes of Descriptive Translation Studies, and of Anthony Pym's position centering the study of translation on material text transfer.

15. This view is developed more specifically in Urien 1991.

16. Baudrillard and Guillaume (1994: 26-27): "Ce que vise la communication est aussi ce qui la fait disparaitre. Autrement dit, toute communication repose sur ce qui lui est contraire et sur la séparation des êtres. C'est pour cela que la communication se nourrit de toutes les formes de mise à distance, d'étrangeté et donc de tous les risques d'incompréhension et de malentendus."

17. The complexity of this anonymity has been addressed in Chapter 3 of Pym 1992 ("I am translating is false," pp. 51-65.) Also see Venuti's historical analysis (1995) of this phenomenon, which he aptely named the "translator's invisibility." 


\section{REFERENCES}

Bourdieu, Pierre and Loïc J. D. Wacquant (1992): Réponses. Pour une anthropologie réflexive, Paris, Seuil, coll. "Libre Examen."

Chesterman, Andrew (1997): Memes of Translation. The Spread of Ideas in Translation Theory, Amsterdam, Benjamin, coll. "Benjamin's Translation Library."

Gagnepain, Jean (1994): Leçons d'introduction à la théorie de la médiation, Louvain-La-Neuve, Peeters, coll. "Anthropo-Logiques," no 5.

— (1982/1991): Du Vouloir Dire. Traité d'épistémologie des sciences humaines, t. 1 ("Du signe, de l'outil," Paris and Oxford, Pergamon Press; t. 2 ("De la personne, de la norme), Paris, Livre et Communication.

Giot, Jean (1997): “De l'écriture: distinction et récurrence de registres d'analyse," Surdité, différences, écritures. Apports de l'anthropologie clinique (Jean Giot and Jean-Claude Sснотте, eds), Brussels, De Boeck, coll. "Raisonnances," pp. 77-114.

Giот, Jean and Jean-Claude Sснотте, eds (1997): Surdité, différences, écritures. Apports de l'anthropologie clinique, Brussels, De Boeck, coll. "Raisonnances."

GutT, Ernst-August (1990): "A theoretical account of translation — without a theory of translation," Target, 2-2, pp. 135-164.

Hermans, Theo (1999): Translation in Systems. Descriptive and System Approaches Explained, Manchester, St. Jerome, coll. “Translation Theories Explained," $n^{\circ} 7$.

Hjiort, Anne Mette (1990): “Translation and the Consequences of Scepticism," Translation, History and Culture (Susan Bassnett and André Lefevere, eds), London and New York, Pinter Publishers, pp. 38-45.

Lauguier, Sandra (1996): "Relativité linguistique, Relativité anthropologique," Histoire. Epistémologie. Langage, $\mathrm{n}^{\circ}$ 1, pp. 45-73.

LÉvy-Leblond, Jean-Marc (1996): La pierre de touche. La science à l'épreuve..., Paris, Gallimard, coll. "Folio Essais."

Malmkjaer, Kirsten (1993): “Underpinning Translation Theory," Target, 5-2, pp. 133-148.

Peeters, Jean (1993): “À propos du service de traduction,” Tétralogiques, 10, pp. 199-212.

- (1999): La Médiation de l'étranger. Une Sociolinguistique de la Traduction, Arras, Presses de l'Université d'Artois, coll. "Traductologie."

Pym, Anthony (1992): Translation and Text Transfer. An Essay on the Principles of Intercultural Communication, FfM; Berlin, Bern, New York, Paris and Wien, Peter Lang, coll. "Publikationen des Fachsbereichs Angewandte Sprach- und Kulturwissenschaft (FASK) der Johannes Gutenberg Universität Mainz in Germersheim,” vol. 16.

- (1998): Method in Translation History, Manchester, St. Jerome Publishing.

Sснотте, Jean-Claude (1997): La raison éclatée. Pour une dissection de la connaissance, Paris and Brussels, De Boeck \& Larcier, coll. "Raisonnances."

- (1997a): "L'approche clinique en sciences humaines," Surdité, différences, écritures. Apports de l'anthropologie clinique (Jean Giot and Jean-Claude Sснотте, eds), Brussels, De Boeck, coll. "Raisonnances," pp. 4-15.

Urien, Jean-Yves (1991): “Le langage en plan(s)," Anthropo-logiques, 3, pp. 11-37.

Venuti, Lawrence (1995): The Translator's Invisibility. A History of Translation in the West, London, Routledge. 